\title{
CORE REQUIREMENTS OF KNOWLEDGE MANAGEMENT IMPLEMENTATION, INNOVATION AND ORGANIZATIONAL PERFORMANCE
}

\author{
Laith Ali AL-HAKIM ${ }^{1}$, Shahizan HASSAN ${ }^{2}$ \\ ${ }^{1}$ Faculty of Administration and Economics, University of Kufa, Najaf, Iraq \\ ${ }^{2}$ Othman Yeop Abdullah Graduate School of Business, University Utara Malaysia, \\ Sintok, Kedah, Malaysia \\ E-mails: ${ }^{1}$ laitha.alhakim@uokufa.edu.iq (correspondingauthor); ${ }^{2}$ shahizan@uum.edu.my \\ Received 11 February 2012; accepted 06 August 2012
}

\begin{abstract}
The present study aims to examine the relationship among core requirements of knowledge management implementation, innovation, and organizational performance in the Iraqi mobile telecommunications sector. A questionnaire was conducted on mobile companies based on a proportionate stratified random sampling technique. The results indicated that core requirements of knowledge management implementation had a statistically significant and direct positive effect on innovation. The critical success factors of knowledge management and knowledge management strategies had a statistically significant and direct positive effect on organizational performance. Then the direct relationship of knowledge management processes with organizational performance was positively affected, but it was not statistically significant. The results also indicated that the innovation had a positive and statistically significant effect on organizational performance. More importantly, the results indicate that core requirements of knowledge management implementation had a positive and statistically significant effect on organizational performance through the partial mediating effect of innovation.
\end{abstract}

Keywords: core requirements, knowledge management, implementation, innovation, organizational performance, mobile telecommunications sector.

JEL Classification: D2, C32, L2, M21, O22.

\section{Introduction}

In today's Mobile Telecommunication Sector (MTS), we see an increasing and fierce competition between companies due to continuous innovation brought by technological development and advancements. In this regard, enhancing innovation has been recognized as an important substance of Organizational Performance (OP) improvement in this sector (Al-hakim, Hassan 2013; Jaspers et al. 2007; Oke 2007). However, an intensive review of the literature reveals that only a small number of empirical studies have discussed innovation as an important part of the OP in the MTS (Chong et al. 2009; Oke 2007). Thus, there is a need for researchers to identify the practical way to enhance innovation toward improving OP in the MTS. From Resource-Based View (RBV) and 
Knowledge-Based View (KBV) theories' perspectives, superior organizations depend more on their knowledge-based resources to survive (Choi et al. 2008; Ho 2008; Kim, Gong 2009) and to improve OP (Liao, Wu 2009).

Knowledge Management (KM) is important to increase innovation in new mobile services (Lin 2007; Sáenz et al. 2009). Apart from that, KM implementation can help the organization improve its performance by creating knowledge-based innovation (Darroch 2005; Rhodes et al. 2008). In short, the main outcome of KM implementation is enhanced innovation and improved OP (Jafari et al. 2007). Based on the above, the present study attempts to highlight the significant role of KM implementation in enhancing innovation and improving OP. Thus, based on previous studies on KM (e.g. Asoh et al. 2007; Anderson 2009; Choi et al. 2008; Chong et al. 2009; Kim, Gong 2009; Liao, Wu 2009; Zack et al. 2009), the question of how can organisations implement KM successfully, remain unanswered.

Briefly, the Iraqi mobile telecommunications companies have not been able to successfully implement KM due to lack of understanding of the core requirements of KM. This has led to the decline in innovation and OP in the Iraqi MTS. Thus, present study seeks to address the issue of KM implementation from a comprehensive view and investigate it's related to innovation and OP. In particular, present study seeks to examine four aspects of this relationship (i) the direct relation between core requirements of the $\mathrm{KM}$ implementation and innovation; (ii) the direct relation between core requirements of the KM implementation and OP; (iii) the direct relation between innovation and OP, and (iv) the indirect relation of the core requirements of the KM implementation with OP through innovation.

\section{Theoretical background and hypotheses}

\subsection{The core requirements of $K M$ implementation in the MTS}

Numerous studies have shown that KM implementation is able to help achieve or maintain success of contemporary organizations. KM implementation is said to be the best way to improve organization's ability in various aspects such as innovation (Brachos et al. 2007; Chen, Huan 2009; Chang, Lee 2008; Liao, Wu 2010; Sáenz et al. 2009) and OP (Asoh et al. 2007; Choi et al. 2008; Ho 2008; Kim, Gong 2009; Liao, Wu 2009; Zack et al. 2009). Therefore, researchers have resorted to the development of several frameworks to achieve successful KM implementation. But these frameworks differ in their orientation depending on the different viewpoints of the researchers (Shahrokhi 2010). The KM framework is defined as a guide to implement knowledge management in an organized way (Elashaheb 2005; Kim 2009). There are a many KM implementation frameworks in the literature. Despite this, many organizations are still not able to implement KM successfully. This may be due to the limited comprehensive framework in this area (Kim 2009; Shahrokhi 2010; Yang et al. 2009). Review of literatures identifies 23 frameworks of KM implementation that involves three main elements (i.e. CSFs of KM, KMSs, and KMPs). These three elements have been widely acknowledged in the literature as core requirements of successful KM implementation (Ajmal et al. 2010; Jafari et al. 2010). 


\subsection{Innovation in the mobile telecommunication sector}

The rapid dissemination of mobile technology is mostly due to technological growth. In this regard, it sets technological innovation at the high-level of the mobile company's strategic goals. Furthermore, the increased number of mobile subscribers and the high competition between mobile companies set the impetus for enhanced technological innovation (Mufioz 2008). Subsequently, these companies are seeking to mandatory achievement of it, through supported administrative, radical, and incremental innovation (Jaspers et al. 2007; Oke 2007) in order to survive.

In the MTS context, technological innovation is the knowledge that links methods, components, and techniques with processes to create services (Popadiuk, Choo 2006). Administrative innovation refers to the changes in organisational structure and processes, like the authority, tasks structuring, personnel recruitment, resources allocation and rewards (Lin et al. 2010). Radical innovation is a main change that represents a new technological pattern (Pedersen, Dalum 2004), and requires more organisational capabilities and superior profundity of knowledge (Darroch, McNaughton 2005; Roberts 2008). Incremental innovation is defined as cumulative and gradual nature of technological changes in organisation to create services (Pedersen, Dalum 2004). As such, unlike incremental innovation, it does not require much organisational capability (Darroch, McNaughton 2005; Roberts 2008).

\subsection{Organizational performance in the mobile telecommunication sector}

OP improvement in the MTS depend on many factors such as technology standards (Jho 2007), market, competition, organisational structure (Palcic, Reeves 2010), foreign direct investment (Lin 2008), company management, financial resource and technological development (Caia, Tylecote 2008). But among these factors, the growth of the MTS depends mainly on technological development and innovation, as argued by many scholars (Chen et al. 2007; Gao, Rafiq 2009; Lee, Park 2008; Oke 2007). In this regard, Gao and Rafiq (2009) observed that technological innovation has been identified as the critical success factor in the MTS growth in developing countries. He also revealed that creating a new mobile service is closely related to the adoption of technological innovation and that leads to improve the overall OP of MTS. In other words, without technological innovation, accomplishing OP in the MTS will be difficult. Subsequently, the researcher is interested in investigating the relationship between innovation and OP in the Iraqi MTS.

Indeed, the OP indicators (financial, customer, internal process, and learning and growth) have become an important issue in evaluating organizational success (Moullin 2007). It is defined as "comparing the expected results with the actual ones, investigating deviations from plans, assessing individual performance and examining progress made towards meeting the targeted objectives" (Ngah, Ibrahim 2010: 503). Based on this definition, OP indicators can provide assistance for managers to evaluate the organizational activities and maintain the competitive position or superiority over competitors (Visser, Sluiter 2007). 


\subsection{Relationships among the variables of the present study}

\subsubsection{Knowledge management and innovation}

\subsubsection{Critical success factors of KM implementation and innovation}

In superior organisations, it is important to determine the CSFs of KM that enhance innovation (Chang, Lee 2008; Chen, Huang 2009). In spite of past investigation, there are very few previous studies that examined the relationship between CSFs of KM and innovation from a comprehensive viewpoint (Brachos et al. 2007; Chang, Lee 2008; Chen, Huang 2009; Liao, Wu 2010; Lin 2007; Rhodes et al. 2008). Some studies have shown that CSFs of KM do have a significant and positive relationship to innovation. Thus, it is expected that:

H1: CSFs of KM have a significant and positive effect on innovation.

\subsubsection{Knowledge management strategies and innovation}

Even though KMSs are regarded as the best way to enhance innovation (Majchrzak et al. 2004; Rhodes et al. 2008). There have been few empirical studies that have examined the relationship between KMSs and innovation. However, Majchrzak et al. (2004) concluded that explicit knowledge reuse (considered a codification strategy) has a significant and positive relationship to radical innovation. Rhodes et al. (2008) found that personalisation strategy has a significant and positive related to product innovation and process innovation. Thus, it is expected that:

H2: KMSs have a significant and positive effect on innovation.

\subsubsection{Knowledge management processes and innovation}

In fact, the effect of KMPs plays a vital role in the continuity of innovation (Darroch, 2005; Wei, Xie 2008). Despite in Darroch and McNaughton's (2002) research identified mixed results in the relationship between KMPs and innovation. A number of recent empirical studies showed a significant and positive relationship of KMPs with innovation, such as Chang and Lee (2008), Darroch (2005), Huang and Li (2009), Ju et al. (2006), Liao and $\mathrm{Wu}$ (2010), and Wei and Xie (2008). Thus, it is expected that:

H3: KMPs have a significant and positive effect on innovation.

\subsubsection{Knowledge management and organizational performance}

\subsubsection{Critical success factors of knowledge management and organizational performance}

Even with a large body of literature documenting how CSFs of KM influence OP, no study gathers all the CSFs of KM that may affect OP in one research (Anderson 2009; Asoh et al. 2007; Gold et al. 2001), particularly in the MTS context (Chong et al. 2009). In any case, previous empirical studies have shown that CSFs of KM have a significant and positive relationship with OP. Thus, it is expected that:

H4: CSFs of KM have a significant and positive effect on OP. 


\subsubsection{Knowledge management strategies and organizational performance}

KMSs are becoming increasingly important assets for organisations throughout the world (Schulz, Jobe 2001; Yu et al. 2006). In simple terms, they lead to perfect OP, particularly in the MTS context (Chong et al. 2009). Yet few empirical studies have concentrated on determining the effect of KMSs on different indicators of OP (Bierly, Daly 2007). However, Choi and Lee (2003), Choi et al. (2008), and Keskin (2005) demonstrated that KMSs (codification strategy and personalisation strategy) are positively and statistically significantly related to OP. Thus, it is expected that:

H5: KMSs have a significant and positive effect on OP.

\subsubsection{Knowledge management processes and organizational performance}

KMPs are becoming the most valuable activities for any organisation (Chang, Chuang 2011; Darroch 2005; Fugate et al. 2009). In specific terms, they lead all organisational efforts to achieve an ideal OP, particularly in the MTS context (Chong et al. 2009). However, understanding of how KMPs are related to OP is limited due to the mixed and not significant results in prior studies that examined the relationship between KMPs and OP (Anderson 2009; Darroch 2005; Zack et al. 2009). However, a number of recent empirical studies have shown how KMPs are significantly and positively to OP; these studies include Asoh et al. (2007), Chang and Chuang (2011), Fugate et al. (2009), Gold et al. (2001), Ho (2008), Y. C Lee and S. K. Lee (2007), and Liao and Wu (2009). Thus, it is expected that:

H6: KMPs have a significant and positive effect on OP.

\subsubsection{Innovation and organizational performance}

Prior research provides evidence that effective innovation types are a key instrument for OP (Damanpour et al. 2009; García-Morales et al. 2008; Li et al. 2006). However, more research is needed due to the complex relationship between innovation and OP (Damanpour et al. 2009). In this case, some studies have shown that innovation (including technological innovation, administrative innovation, radical innovation, and incremental innovation) is positively related to OP (Chen et al. 2009; Damanpour et al. 2009; Li et al. 2006; Lin, Chen 2007). For instance, Chen et al. (2009) found that innovation in technological and administrative have a positive and significant effect on OP. Furthermore, Lin and Chen (2007) argued that radical innovation and incremental innovation have a positive relationship with OP. Thus, it is expected that:

H7: Innovation has a significant and positive effect on OP.

\subsubsection{Possible mediating role of innovation}

The extant literature reveals that a gap remains in the innovation field, particularly in the determination of the significant factors that have a direct effect on innovation to improve OP (Aragón-Correa et al. 2007; García-Morales et al. 2007). In this regard, the indirect relationship between core requirements of KM implementation (CSFs of KM, KMSs, and KMPs) and OP (financial perspective, customer perspective, internal process perspective, and learning and growth perspective) through innovation (technological innovation, administrative innovation, radical innovation, and incremental in- 
novation) has never been previously explored within a single study. In such conditions, where a relationship has never been previously explored, an indirect hypothesis should be formulated. Therefore, in line with many researchers (Aragón-Correa et al. 2007; García-Morales et al. 2007), the present study proposes that innovation plays a significant and positive mediating role in the relationship between core requirements of KM implementation and OP, based on RBV and KBV theories' perspectives that provide a theoretical basis for explaining the influence of KM implementation on OP through innovation. Thus, it is expected that:

H8: Innovation has a significant and positive mediating effect on the relationship between the CSFs of KM and OP.

H9: Innovation has a significant and positive mediating effect on the relationship between KMSs and OP.

H10: Innovation has a significant and positive mediating effect on the relationship between KMPs and OP.

\subsection{Proposed research model}

The framework, based on RBV and KBV theories' perspectives, is conceptualized based on a number of previous studies (Anderson 2009; Asoh et al. 2007; Chen, Huang 2009; Damanpour et al. 2009; Fugate et al. 2009; Darroch 2005; Liao, Wu 2009; Li et al. 2006; Zack et al. 2009). Then, the research framework of the present study is shown in Figure 1.

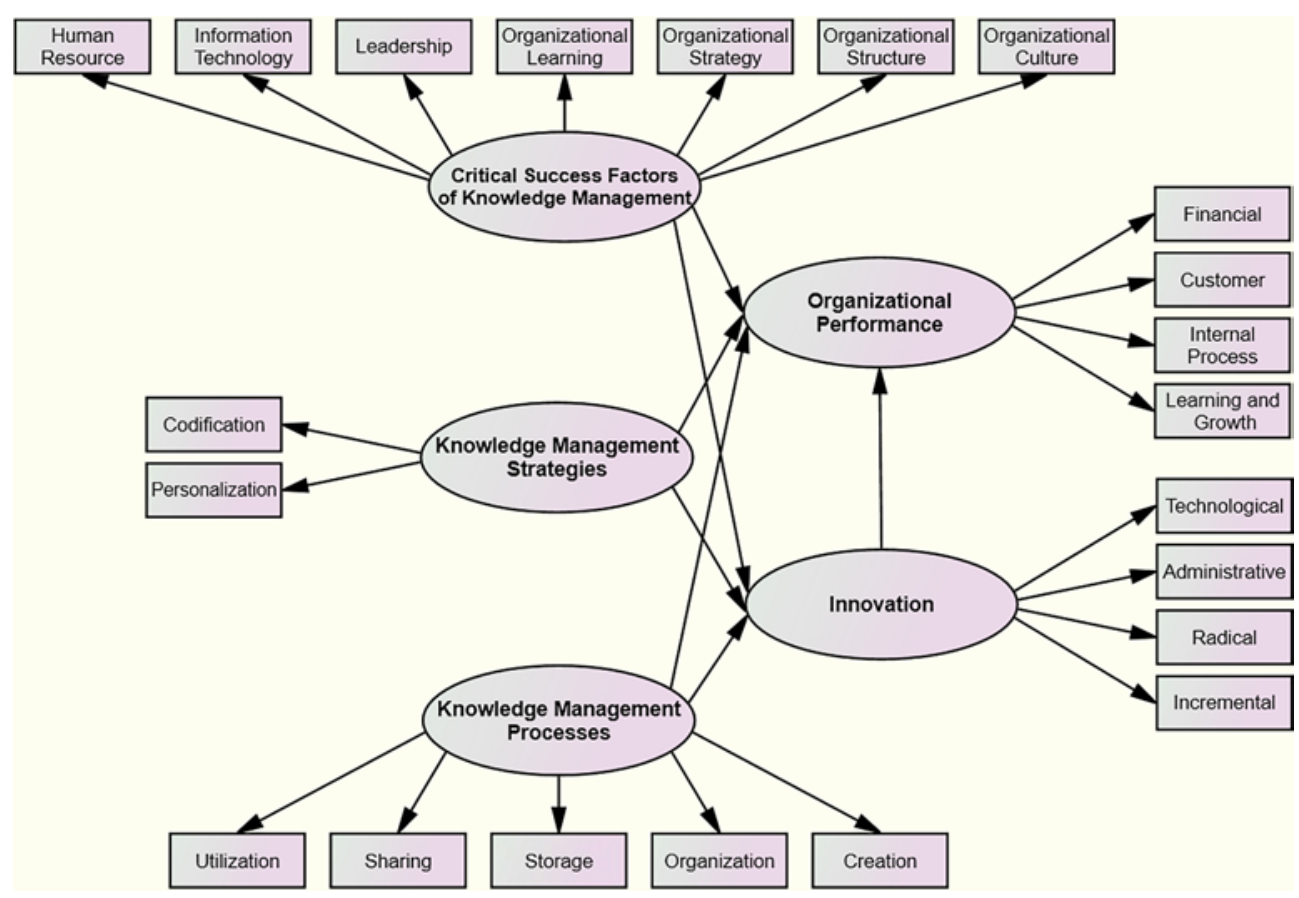

Fig. 1. Theoretical framework of the study 
As contributions to the body of knowledge, the proposed theoretical framework shown in Figure 1 describes the causal relationships among five variables of the CSFs of KM, KMSs, KMPs, innovation, and OP. The independent variables in this framework are the CSFs of KM, KMSs, and KMPs. On the other hand, the dependent variable is OP. Innovation acts as the mediating variable between the core requirements of KM implementation and OP. The framework comprehensively takes into account all the pertinent variables that affect OP within the knowledge field in a single study.

\section{Methodology}

\subsection{Target population}

In the present study, the population refers to all mid-level managers from different branches and direct sales centers of the private Iraqi mobile companies. In line with previous research, present study chooses mid-level managers of Iraqi MTS as target respondents because of their role in the successful KM implementation (Al-hakim, Hassan 2014).

\subsection{Sample and procedures}

Based on an application of proportionate stratified random sampling technique, questionnaires were randomly distributed only among 300 mid-level managers of the Iraqi MTS by personal delivery and collection of questionnaires from March to June 2011. From the 300 questionnaires randomly distributed, only 233 questionnaires were returned for a response rate of $77.67 \%$. Out of these responses, $1 \%$ of the 3 questionnaires were unusable because the respondents did not complete all of the questions. Thus, $76.67 \%$ of the 230 questionnaires were used in the analysis. After screening, $3.33 \%$ of 10 questionnaires were found to be outliers. Therefore, the final total usable response rate was $73.34 \%$ of the 220 questionnaires.

\subsection{Measures}

In the present study, most of 110 measurement items were adapted from previous questionnaires, with the exception of one item for KMPs, one item for innovation, and four items from OP, which were developed by researchers (see Table 1). Moreover, present study seeks to measure all variables by using a 5-point Likert scale where survey question is referred to agreement degree (i.e. $1=$ strongly disagree, and $5=$ strongly agree). 
Table 1. Measurement instrument

\begin{tabular}{|c|c|c|c|c|}
\hline Variable & Dimension & $\begin{array}{c}\text { Original } \\
\text { no. of } \\
\text { item }\end{array}$ & $\begin{array}{c}\text { Original } \\
\text { Cronbach's } \\
\text { alpha value }\end{array}$ & Sources \\
\hline \multirow[t]{7}{*}{$\begin{array}{l}\text { CSFs } \\
\text { of KM }\end{array}$} & $\begin{array}{l}\text { Human Resource } \\
\text { (HR) }\end{array}$ & 5 & .834 & Wong and Aspinwall (2005) \\
\hline & $\begin{array}{l}\text { Information } \\
\text { Technology (IT) }\end{array}$ & 5 & .956 & Chong et al. (2009) \\
\hline & Leadership (LE) & 5 & .955 & Chong et al. (2009) \\
\hline & $\begin{array}{l}\text { Organisational } \\
\text { Learning (OL) }\end{array}$ & 5 & .896 & Choi (2002) \\
\hline & $\begin{array}{l}\text { Organisational } \\
\text { Strategy (OS) }\end{array}$ & 5 & .926 & Chong et al. (2009) \\
\hline & $\begin{array}{l}\text { Organisational } \\
\text { Structure }(\mathrm{OT})\end{array}$ & 5 & .912 & Hsieh (2007) \\
\hline & $\begin{array}{l}\text { Organisational } \\
\text { Culture (OC) }\end{array}$ & 5 & .924 & Chong et al. (2009) \\
\hline \multirow[t]{2}{*}{ KMSs } & $\begin{array}{l}\text { Codification } \\
\text { Strategy (CS) }\end{array}$ & 5 & .766 & Kumar and Ganesh (2011) \\
\hline & $\begin{array}{l}\text { Personalisation } \\
\text { Strategy (PS) }\end{array}$ & 5 & .712 & Kumar and Ganesh (2011) \\
\hline \multirow[t]{7}{*}{ KMPs } & $\begin{array}{l}\text { Knowledge } \\
\text { Creation (KC) }\end{array}$ & 5 & .780 & Gómez and Manzanares (2004) \\
\hline & \multirow{2}{*}{$\begin{array}{l}\text { Knowledge } \\
\text { Organization (CO) }\end{array}$} & 4 & .861 & Lawson (2003) \\
\hline & & 1 & \multicolumn{2}{|c|}{$\begin{array}{l}\text { Developed based on the theoretical study } \\
\text { of Bhatt }(2000)\end{array}$} \\
\hline & \multirow{2}{*}{$\begin{array}{l}\text { Knowledge } \\
\text { Storage (KS) }\end{array}$} & 4 & .879 & Lawson (2003) \\
\hline & & 1 & \multicolumn{2}{|c|}{$\begin{array}{l}\text { Developed based on the study of Supyuenyong } \\
\text { et al. (2009) }\end{array}$} \\
\hline & $\begin{array}{l}\text { Knowledge } \\
\text { Sharing (KH) }\end{array}$ & 5 & .750 & Calantone et al. (2002) \\
\hline & $\begin{array}{l}\text { Knowledge } \\
\text { Utilization }(\mathrm{KU})\end{array}$ & 5 & .868 & Chen (2007) \\
\hline \multirow[t]{5}{*}{ Innovation } & $\begin{array}{l}\text { Technological } \\
\text { Innovation (TI) }\end{array}$ & 5 & .730 & Li et al. (2006) \\
\hline & $\begin{array}{l}\text { Administrative } \\
\text { Innovation (AI) }\end{array}$ & 5 & .878 & Lin et al. (2010) \\
\hline & $\begin{array}{l}\text { Radical Innovation } \\
(\mathrm{RI})\end{array}$ & 5 & .900 & Herrmann et al. (2007) \\
\hline & $\begin{array}{l}\text { Incremental } \\
\text { Innovation (NI) }\end{array}$ & 4 & .860 & $\begin{array}{l}\text { Darroch (2005), Darroch } \\
\text { and McNaughton (2002) }\end{array}$ \\
\hline & & 1 & \multicolumn{2}{|c|}{$\begin{array}{l}\text { Developed based on the theoretical study of } \\
\text { Salavou (2004) }\end{array}$} \\
\hline
\end{tabular}


End of Table 1

\begin{tabular}{|c|c|c|c|c|}
\hline Variable & Dimension & $\begin{array}{l}\text { Original } \\
\text { no. of } \\
\text { item }\end{array}$ & $\begin{array}{c}\text { Original } \\
\text { Cronbach's } \\
\text { alpha value }\end{array}$ & Sources \\
\hline \multirow[t]{8}{*}{$\mathrm{OP}$} & \multirow{2}{*}{$\begin{array}{l}\text { Financial } \\
\text { Perspective (FP) }\end{array}$} & 4 & .970 & Gonzalez-Padron et al. (2010) \\
\hline & & 1 & $\begin{array}{l}\text { Developed b } \\
\text { Visser and } \mathrm{S}\end{array}$ & $\begin{array}{l}\text { ased on the theoretical study of } \\
\text { luiter (2007) }\end{array}$ \\
\hline & \multirow{2}{*}{$\begin{array}{l}\text { Customer } \\
\text { Perspective (CP) }\end{array}$} & 4 & .930 & Gonzalez-Padron et al. (2010) \\
\hline & & 1 & $\begin{array}{l}\text { Developed b } \\
\text { Visser and S }\end{array}$ & $\begin{array}{l}\text { ased on the theoretical study of } \\
\text { luiter (2007) }\end{array}$ \\
\hline & \multirow{2}{*}{$\begin{array}{l}\text { Internal Process } \\
\text { Perspective (IP) }\end{array}$} & 4 & .950 & Gonzalez-Padron et al. (2010) \\
\hline & & 1 & $\begin{array}{l}\text { Developed b } \\
\text { Visser and } S\end{array}$ & $\begin{array}{l}\text { ased on the theoretical study of } \\
\text { luiter (2007) }\end{array}$ \\
\hline & \multirow{2}{*}{$\begin{array}{l}\text { Learning } \\
\text { and Growth } \\
\text { Perspective (GP) }\end{array}$} & 4 & .960 & Gonzalez-Padron et al. (2010) \\
\hline & & 1 & $\begin{array}{l}\text { Developed } \mathrm{b} \\
\text { Visser and } \mathrm{S}\end{array}$ & $\begin{array}{l}\text { ased on the theoretical study of } \\
\text { luiter (2007) }\end{array}$ \\
\hline $\begin{array}{l}\text { Total } \\
\text { instruments }\end{array}$ & 110 & & & \\
\hline
\end{tabular}

\section{Analysis and results}

\subsection{Structural model}

In order to test the substantive hypotheses, a final structural model was developed. It was run with 48 items to assess three exogenous latent variables (CSFs of KM, KMSs, and KMPs) and two endogenous latent variables (innovation and OP). Only 45 items of overall exogenous and endogenous latent variables were presented in this model. This is because the overall results presented evidence of a good model fit ( $p=.369$, GFI $=$ $.903, \mathrm{CFI}=.995, \mathrm{TLI}=.995$, and RMSEA $=.008)$ and the Chi-square index was significant $\left(\chi^{2}=926.711, \mathrm{df}=913, \chi^{2} / \mathrm{df}=1.015\right)$. Hence, it can be concluded that these conditions meet the requirement of an acceptable model. The final structural model is shown in Figure 2.

\subsection{Hypotheses testing and discussion}

SEM analysis was used to test the ten hypotheses proposed in the present study. The result of this analysis is used to accept or reject the hypotheses based on the significance of the standardized path coefficient of the relationships and C.R. value. The test of these hypotheses is presented as follows:

\subsubsection{Direct relationships}

The direct relationships in SEM are the relations that go directly from one exogenous latent variable to endogenous latent variable. Below, Table 2 shows the status of seven hypotheses in final structural model. 


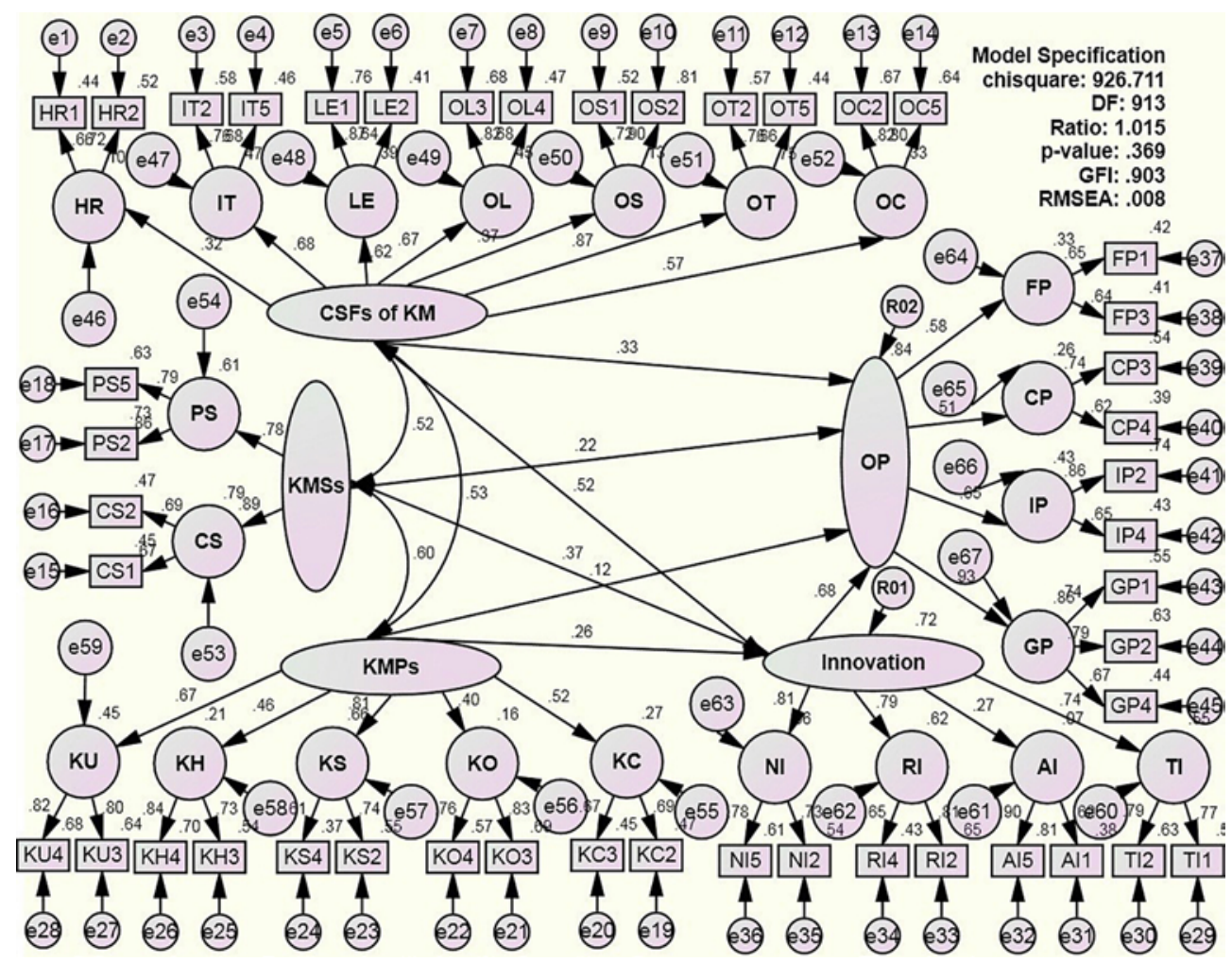

Fig. 2. Final structural model

Table 2. Direct relationships in final structural model

\begin{tabular}{|c|c|c|c|c|c|c|c|c|c|}
\hline $\begin{array}{l}\text { Hypoth- } \\
\text { esis }\end{array}$ & $\mathrm{Cau}$ & usal $\mathrm{P}$ & & $\begin{array}{l}\text { Sta. Path } \\
\text { Coefficient }\end{array}$ & $\begin{array}{l}\text { Esti- } \\
\text { mate }\end{array}$ & S.E. & C.R. & $P$ & Status \\
\hline $\mathrm{H} 1$ & $\begin{array}{l}\text { Innova- } \\
\text { tion }\end{array}$ & $<---$ & $\begin{array}{l}\text { CSFs } \\
\text { of KM }\end{array}$ & .522 & 1.169 & .212 & 5.504 & $.000 * * *$ & $\begin{array}{l}\text { Significantly } \\
\text { Positively Related }\end{array}$ \\
\hline $\mathrm{H} 2$ & $\begin{array}{l}\text { Innova- } \\
\text { tion }\end{array}$ & $<---$ & KMSs & .371 & 1.158 & .459 & 2.525 & $.012 * *$ & $\begin{array}{l}\text { Significantly } \\
\text { Positively Related }\end{array}$ \\
\hline $\mathrm{H} 3$ & $\begin{array}{l}\text { Innova- } \\
\text { tion }\end{array}$ & $<---$ & KMPs & .264 & .315 & .154 & 2.049 & $.041 * *$ & $\begin{array}{l}\text { Significantly } \\
\text { Positively Related }\end{array}$ \\
\hline $\mathrm{H} 4$ & OP & $<---$ & $\begin{array}{l}\text { CSFs } \\
\text { of KM }\end{array}$ & .329 & 1.448 & .618 & 2.343 & $.019 * *$ & $\begin{array}{l}\text { Significantly } \\
\text { Positively Related }\end{array}$ \\
\hline H5 & OP & $<---$ & KMSs & .221 & .332 & .163 & 2.031 & $.042 * *$ & $\begin{array}{l}\text { Significantly } \\
\text { Positively Related }\end{array}$ \\
\hline H6 & OP & $<---$ & KMPs & .123 & .088 & .105 & .840 & .401 & $\begin{array}{l}\text { Non-Significantly } \\
\text { Positively Related }\end{array}$ \\
\hline $\mathrm{H} 7$ & OP & $<---$ & $\begin{array}{l}\text { Innova- } \\
\text { tion }\end{array}$ & .681 & .624 & .146 & 4.276 & $.000 * * *$ & $\begin{array}{l}\text { Significantly } \\
\text { Positively Related }\end{array}$ \\
\hline
\end{tabular}

Note: **Significant at .05 level and *** Significant at .001 level. 


\subsubsection{Indirect relationships (mediating relationships)}

Indirect relationship or mediating relationship is formed when a third variable mediates between two exogenous latent variables. The mediating effect were tested among CSFs of KM, KMSs, and KMPs mediated by innovation with OP (see Table 3).

Table 3. Indirect relationships of final structural model

\begin{tabular}{clccc}
\hline Hypothesis & \multicolumn{1}{c}{ Causal Path } & $\begin{array}{c}\text { Indirect } \\
\text { Relation } \\
\text { Estimate }\end{array}$ & $\begin{array}{c}\text { Direct } \\
\text { Relation } \\
\text { Estimate }\end{array}$ & Status \\
\hline H8 & CSFs of KM $\rightarrow$ Innovation $\rightarrow$ OP & .355 & .329 & Partial Mediating \\
\hline H9 & KMSs $\rightarrow$ Innovation $\rightarrow$ OP & .252 & .221 & Partial Mediating \\
\hline H10 & KMPs $\rightarrow$ Innovation $\rightarrow$ OP & .179 & .123 & Partial Mediating \\
\hline
\end{tabular}

\section{Conclusions, limitations, and future directions}

The present study has sought to investigate the mediating role of innovation in the relationships between core requirements of KM implementation and OP in the Iraqi MTS context. It has met all the questions and objectives as outlined in chapter one. Certainly, it augments our understanding of the core requirement of KM implementation (CSFs of KM, KMSs, and KMPs) in enhancing innovation (technological innovation, administrative innovation, radical innovation, and incremental innovation) and improving OP (financial perspective, customer perspective, internal process perspective, and learning and growth perspective). Based on the RBV and KBV theories' perspectives, the results of the present study provided evidence that all the core requirements of KM implementation have a significant and positive effect on innovation and OP, except the KMPs, which has a positive but not significant effect on OP.

Furthermore, the results indicated that innovation has a significant and positive effect on OP. The results also show that the KM implementation (CSFs of KM, KMSs, and KMPs) has a positive and statistically significant effect on OP through the partial mediating role of innovation. Consequently, the present study has contributed to the KM implementation field. The findings of the present study have theoretical, methodological, and practical contributions.

As such, the current attempt has managed to fill in gaps that existed in the KM implementation literature. However, the present study faced methodological and generalisability limitations. In this case, further studies are necessary to confirm these results and incorporate the other variables that may have influenced the results. Therefore, the future is wide open for further empirical research in this area. 


\section{References}

Ajmal, M.; Helo, P.; Keka, T. 2010. Critical factors for knowledge management in project business, Journal of Knowledge Management 14(1): 156-168.

http://dx.doi.org/10.1108/13673271011015633

Al-hakim, L.; Hassan, S. 2013. Knowledge management strategies, innovation, and organisational performance: an empirical study of the Iraqi MTS, Journal of Advances in Management Research 10(1): 58-71. http://dx.doi.org/10.1108/09727981311327767

Al-hakim, L.; Hassan, S. 2014. Who are the Crew members on implementation of knowledge management strategies to enhance innovation and improve organizational performance, Journal of Resources Development and Management 3: 54-63.

Anderson, K. K. 2009. Organizational capabilities as predictors of effective knowledge management: an empirical examination: unpublished doctoral dissertation. Southeastern University, US.

Aragón-Correa, J. A.; García-Morales, V. J.; Cordón-Pozo, E. 2007. Leadership and organizational learning's role on innovation and performance: lessons from Spain, Industrial Marketing Management 36(3): 349-359. http://dx.doi.org/10.1016/j.indmarman.2005.09.006

Asoh, D. A.; Belardo, S.; Crnkovic, J. 2007. Assessing knowledge management: REFINING and cross validating the knowledge management index using SEM Techniques, International Journal of Knowledge Management 3(2): 1-30. http://dx.doi.org/10.4018/jkm.2007040101

Bierly, P. E.; Daly, P. S. 2007. Alternative knowledge strategies, competitive environment, and organizational performance in small manufacturing firms, Entrepreneurship Theory and Practice 31(4): 493-516. http://dx.doi.org/10.1111/j.1540-6520.2007.00185.x

Brachos, D.; Konstantinos, K.; Soderquist, K. E.; Prastacos, G. 2007. Knowledge effectiveness, social context and innovation, Journal of Knowledge Management 11(5): 31-44.

http://dx.doi.org/10.1108/13673270710819780

Caia, J.; Tylecoteb, A. 2008. Corporate governance and technological dynamism of Chinese firms in mobile telecommunications: a quantitative study, Research Policy 37(10): 1790-1811. http://dx.doi.org/10.1016/j.respol.2008.07.004

Chang, S. C.; Lee, M. S. 2008. The linkage between knowledge accumulation capability and organizational innovation, Journal of Knowledge Management 12(1): 3-20.

http://dx.doi.org/10.1108/13673270810852359

Chang, T. C.; Chuang, S. H. 2011. Performance implications of knowledge management processes: examining the roles of infrastructure capability and business strategy, Expert Systems with Applications 38(5): 6170-6178. http://dx.doi.org/10.1016/j.eswa.2010.11.053

Chen, C.; Huang, J. 2009. Strategic human resource practices and innovation performance the mediating role of knowledge management capacity, Journal of Business Research 62(1): 104-114. http://dx.doi.org/10.1016/j.jbusres.2007.11.016

Chen, J.; Liu, Z. C.; Wu, N. Q. 2009. Relationships between organizational learning, innovation and performance: an empirical examination, IEEE Xplore, 488-492.

Chen, L. 2007. Linking knowledge management to organizational business performance: unpublished doctoral dissertation. Griffith University, Australia.

Chen, L.; Mohamed, S. 2008. Contribution of knowledge management activities to organisational business performance, Journal of Engineering, Design and Technology 6(3): 269-285.

http://dx.doi.org/10.1108/17260530810918289

Choi, B. 2002. Knowledge management enablers, process, and organizational performance: an integration and empirical examination: unpublished doctoral dissertation. Korea Advanced Institute of Science and Technology, Korea. 
Choi, B.; Lee, H. 2003. An empirical investigation of KM styles and their effect on corporate performance, Information \& Management 40(5): 403-417.

http://dx.doi.org/10.1016/S0378-7206(02)00060-5

Choi, B.; Poon, S. K.; Davis, J. G. 2008. Effects of knowledge management strategy on organizational performance: a complementarity theory-based approach, Omega 36(2): 235-251.

http://dx.doi.org/10.1016/j.omega.2006.06.007

Chong, C. W.; Choy, C. S.; Wong, K. Y. 2009. Is the Malaysian telecommunication industry ready for knowledge management implementation?, Journal of Knowledge Management 13(1): 69-87. http://dx.doi.org/10.1108/13673270910931170

Damanpour, F.; Walker, R. M.; Combinative, C. N. A. 2009. Effects of innovation types and organizational performance: a longitudinal study of service organizations, Journal of Management Studies 46(4): 650-675. http://dx.doi.org/10.1111/j.1467-6486.2008.00814.x

Darroch, J. 2005. Knowledge management, innovation and firm performance, Journal of Knowledge Management 9(3): 101-115. http://dx.doi.org/10.1108/13673270510602809

Darroch, J.; McNaughton, R. 2002. Examining the link between knowledge management practices and types of innovation, Journal of Intellectual Capital 3(3): 210-22.

http://dx.doi.org/10.1108/14691930210435570

Elashaheb, M. S. 2005. A knowledge management framework for the telecommunication industry: the KMFTI model: unpublished doctoral dissertation. University of Salford, United Kingdom.

Fugate, B. S.; Theodore, P. S.; Mentzer, J. T. 2009. Linking improved knowledge management to operational and organizational performance, Journal of Operations Management 27(3): 247-264. http://dx.doi.org/10.1016/j.jom.2008.09.003

Gao, P.; Rafiq, A. 2009. The transformation of the mobile telecommunications industry in Pakistan: a developing country perspective, Telecommunications Policy 33(5-6): 309-323.

http://dx.doi.org/10.1016/j.telpol.2009.03.001

García-Morales, V. J.; Lloréns-Montesa, F. J.; Verdú-Joverb, A. J. 2007. Influence of personal mastery on organizational performance through organizational learning and innovation in large firms and SMEs, Technovation 27(9): 547-568. http://dx.doi.org/10.1016/j.technovation.2007.02.013

García-Morales, V.; Matías-Reche, F.; Hurtado-Torres, N. 2008. Influence of transformational leadership on organizational innovation and performance depending on the level of organizational learning in the pharmaceutical sector, Journal of Organizational Change 21(2): 188-212.

http://dx.doi.org/10.1108/09534810810856435

Gold, A. H.; Malhotra, A.; Segars, A. H. 2001. Knowledge management: an organizational capabilities perspective, Journal of Management Information Systems 18(1): 185-214.

Gómez, F. G.; Manzanares, M. D. 2004. Knowledge management strategies, innovation and firm performance - an empirical study, in Proceedings of the $5^{\text {th }}$ OKLC Conference, 2-4 April 2004, Innsbruck, Austria, 1-21.

Gonzalez-Padron, T. L.; Chabowski, B. R.; Hult, G. T. M.; Ketchen, D. J. 2010. Knowledge management and balanced scorecard outcomes: exploring the importance of interpretation, learning, and internationality, British Journal of Management 21(4): 967-982.

http://dx.doi.org/10.1111/j.1467-8551.2009.00634.x

Herrmann, A.; Gassmann, O.; Eisert, U. 2007. An empirical study of the antecedents for radical product innovations and capabilities for transformation, Journal Engineering and Technology Management 4(1-2): 92-120.

Ho, L. A. 2008. What affects organizational performance? The linking of learning and knowledge management, Industrial Management \& Data Systems 108(9): 1234-1254.

Hsieh, H. J. 2007. Organizational characteristics, knowledge management strategy, enablers, and process capability: knowledge management performance in U.S. software companies: unpublished doctoral dissertation. Lynn University, U.S. 
Huang, J.; Li, Y. 2009. The mediating effect of knowledge management on social interaction and innovation performance, International Journal of Manpower 30(3): 285-301.

http://dx.doi.org/10.1108/01437720910956772

Jafari, M.; Akhavan, P.; Fesharaki, M. N.; Fathian, M. 2007. Iran aerospace industries' KM approach based on a comparative study: a benchmarking on successful practices, Aircraft Engineering and Aerospace Technology: an International Journal 79(1): 69-78.

http://dx.doi.org/10.1108/00022660710720511

Jafari, M.; Rezaeenour, J.; Akhavan, P.; Fesharaki, M. N. 2010. Strategic knowledge management in aerospace industries: a case study, Aircraft Engineering and Aerospace Technology: an International Journal 82(1): 60-74. http://dx.doi.org/10.1108/00022661011028128

Jaspers, F.; Hulsink, W.; Theeuwes, J. 2007. Entry and innovation in maturing markets: virtual operators in mobile telecommunications, Jules Technology Analysis and Strategic Management 19(2): 205-225. http://dx.doi.org/10.1080/09537320601168144

Jho, W. 2007. Global political economy of technology standardization: a case of the Korean mobile telecommunications market, Telecommunications Policy 31(2): 124-138.

http://dx.doi.org/10.1016/j.telpol.2006.12.004

Ju, T. L.; Li, C. Y.; Lee, T. S. 2006. A contingency model for knowledge management capability and innovation, Industrial Management \& Data Systems 106(5/6): 855-77.

http://dx.doi.org/10.1108/02635570610671524

Keskin, H. 2005. The relationships between explicit and tacit oriented KM strategy, and organization performance, Journal of American Academy of Business, Cambridge 7(1): 169-75.

Kim, H.; Gong, Y. 2009. The roles of tacit knowledge and OCB in the relationship between group-based pay and firm performance, Human Resource Management Journal 19(2): 120-139.

Kim, M. 2009. Paths to knowledge management in small and medium-sized hotels: unpublished doctoral dissertation. RMIT University, Australia.

Kumar, J. A.; Ganesh, L. S. 2011. Balancing knowledge strategy: codification and personalization during product development, Journal of Knowledge Management 15(1): 118-135.

http://dx.doi.org/10.1108/13673271111108738

Lawson, S. 2003. Examining the relationship between organizational culture and knowledge management: unpublished academic dissertation. Nova Southern University, U.S.

Lee, T. M.; Park, C. 2008. Mobile technology usage and B2B market performance under mandatory adoption, Industrial Marketing Management 37(7): 833-840.

http://dx.doi.org/10.1016/j.indmarman.2008.02.008

Lee, Y. C.; Lee, S. K. 2007. Capability, processes, and performance of knowledge management: a structural approach, Human Factors and Ergonomics in Manufacturing 17(1): 21-41.

http://dx.doi.org/10.1002/hfm.20065

Li, Y.; Zhao, Y.; Liu, Y. 2006. The relationship between HRM, technology innovation and performance in China, International Journal of Manpower 27(7): 679-697.

http://dx.doi.org/10.1108/01437720610708284

Liao, S. H.; Wu, C. 2010. System perspective of knowledge management, organizational learning, and organizational innovation, Expert Systems with Applications 37(2): 1096-1103.

http://dx.doi.org/10.1016/j.eswa.2009.06.109

Liao, S. H.; Wu, C. C. 2009. The relationship among knowledge management, organizational learning, and organizational performance, International Journal of Business and Management 4(4): $64-76$.

Lin, C. H. 2008. Role of foreign direct investment in telecommunication industries: a developing countries' perspective, Contemporary Management Research 4(1): 29-42. 
Lin, C. Y.; Chen, M. Y. 2007. Does innovation lead to performance? An empirical study of SMEs in Taiwan, Management Research News 30(2): 115-132.

http://dx.doi.org/10.1108/01409170710722955

Lin, H. 2007. Knowledge sharing and firm innovation capability: an empirical study, International Journal of Manpower 28(3/4): 315-332. http://dx.doi.org/10.1108/01437720710755272

Lin, R. J.; Chen, R. H.; Chiu, K. K. S. 2010. Customer relationship management and innovation capability: an empirical study, Industrial Management \& Data Systems 110(1): 111-133.

Majchrzak, A.; Cooper, L. P.; Neece, O. E. 2004. Knowledge reuse for innovation, Management Science 50(2): 174-188. http://dx.doi.org/10.1287/mnsc.1030.0116

Moullin, M. 2007. Performance measurement definitions linking performance measurement and organizational excellence, International Journal of Health Care Quality Assurance 20(3): 181183. http://dx.doi.org/10.1108/09526860710743327

Mufioz, J. 2008. Success factors in telecom service development: a grounded theory case studies research in the Latin American telecommunication sector: unpublished master's thesis. Carleton University, Canada.

Ngah, R.; Ibrahim, A. R. 2010. The effect of knowledge sharing on organizational performance in small and medium enterprises, in Proceedings of the Knowledge Management $5^{\text {th }}$ International Conference on Knowledge Management: Theory, Research \& Practice, 25-27 May 2010, Terengganu, Malaysia, 503-508.

Oke, A. 2007. Innovation types and innovation management practices in service companies, International Journal of Operations \& Production Management 27(6): 564-587.

http://dx.doi.org/10.1108/01443570710750268

Palcic, D.; Reeves, E. 2010. Organizational status change and performance: the case of Ireland's national telecommunications operator, Telecommunications Policy 34(5-6): 299-308.

http://dx.doi.org/10.1016/j.telpol.2010.03.004

Pedersen, C.; Dalum, B. 2004. Incremental versus radical change - the case of the digital north Denmark program, Paper for the International Schumpeter Society Conference, 9-12 June 2004, Bocconi University, Milan, 1-26.

Popadiuk, S.; Choo, C. W. 2006. Innovation and knowledge creation: how are these concepts related?, International Journal of Information Management 26(4): 302-312.

http://dx.doi.org/10.1016/j.ijinfomgt.2006.03.011

Roberts, D. M. 2008. The integration of service innovation into an existing model for volume \& variety: unpublished doctoral dissertation. Rensselaer Polytechnic Institute, US.

Sáenz, J.; Aramburu, N.; Rivera, O. 2009. Knowledge sharing and innovation performance: a comparison between high-tech and low-tech companies, Journal of Intellectual Capital 10(1): 22-36. http://dx.doi.org/10.1108/14691930910922879

Schulz, M.; Jobe, L. A. 2001. Codification and tacitness as knowledge management strategies: an empirical exploration, Journal of High Technology Management Research 12(1): 139-165. http://dx.doi.org/10.1016/S1047-8310(00)00043-2

Shahrokhi, N. 2010. Designing a model for implementing knowledge management in projectbased organizations: case study of PATSA Co., in Proceedings of the Knowledge Management $5^{\text {th }}$ International Conference on Knowledge Management: Theory, Research \& Practice, 25-27 May 2010, Kuala Terengganu, Malaysia, 335-359.

Visser, J. K.; Sluiter, E. 2007. Performance measures for a telecommunications company, IEEE Xplore, 1-8.

Wei, X.; Xie, F. 2008. Knowledge management processes and innovation: an empirical analysis of firms in software cluster, International Journal of Human Resources Development and Management 8(1-2): 25-42. http://dx.doi.org/10.1504/IJHRDM.2008.018200 
Yang, B.; Zheng, W.; Viere, C. 2009. Holistic views of knowledge management models, Advances in Developing Human Resources 11(3): 273-289. http://dx.doi.org/10.1177/1523422309338584 Yu, C.; Liying, Y. 2009. Performance evaluation of service innovation strategy implementation in enterprise based on BSC, in Proceedings of the International Conference on Management Science and Engineering, 20 November 2009, China, 300-304.

Zack, M.; McKeen, J.; Singh, S. 2009. Knowledge management and organizational performance: an exploratory analysis, Journal of Knowledge Management 13(6): 392-409.

http://dx.doi.org/10.1108/13673270910997088

Laith Ali Yousif AL-HAKIM. Dr Laith Ali Yousif AL-Hakim, a PhD degree holder from the Universiti Utara Malaysia. He is an Asst Prof. in Knowledge Management at the College of Administration and Economics, University of Kufa.

Shahizan HASSAN. Dr Shahizan Hassan, a PhD degree holder from the University of Newcastle upon Tyne, U. Kingdom, is an Associate Professor in Information Systems at the College of Business, University Utara Malaysia (UUM). He is the editor for Malaysian Management Journal (MMJ) and has published four books, fifteen articles in national and international journals, and more than 40 articles in seminar and conferences. His research projects are in the area of Information Systems, Web Design and Evaluation, Knowledge Management, Electronic Government, and Wireless Applications. 